\title{
Educating the Principles of Judiciary in Eastern Europe
}

\section{Educar los principios del poder judicial en Europa del Este}

\author{
Aleksej P. Treskov \\ Rostov State University of Railway Engineering, Russia \\ ORCID: https://orcid.org/0000-0003-4776-4043 \\ Marina V. Markhgeym \\ Belgorod State University, Russia \\ ORCID: https://orcid.org/0000-0001-5195-9199 \\ Tatiana N. Matyusheva \\ Northern Caucasian branch of the «Russian State University of Justice», Russia \\ ORCID: https://orcid.org/0000-0001-7633-1963
}

Galina G. Mikhaleva

Perm State Humanitarian and Pedagogical University, Russia

ORCID: https://orcid.org/0000-0001-5902-9535

Lyudmila A. Tkhabisimova

Pyatigorsk State University, Russia

ORCID: https://orcid.org/0000-0002-0852-3338

Recibido 12-12-19 Revisado 13-02-20 Aprobado 20-04-20 En línea 29-04-20

Correspondencia

Email: altreskov@yandex.ru
Citar como:

Treskov, A. P., Markhgeym, M. V., Matyusheva, T. N., Mikhaleva, G. G., Tkhabisimova, L. A. (2020). Constitutional Specialization of the Judiciary Principles in Eastern Europe. Propósitos y Representaciones, $8(3)$. doi: http://dx.doi.org/10.20511/pyr2020.v8n3.519 


\section{Summary}

The study subject in this article is aims to educate the concepts of judiciary principles in Eastern eroup. We substantiated the conclusion on constitutional structuring of the formalization of judiciary principles in the sections devoted to the state foundations (constitutional system); human and civil rights and freedoms; judiciary; higher judicial authorities (usually the constitutional court). A comparative legal study of the norms of special sections on judiciary contained in the constitutions of Eastern European countries allowed the author forming a list of principles that organize and constitute the basis of activity of this kind of judiciary; identify the specific nature of their consolidation; present quantitative and qualitative features of the declared fundamental principles.

Keywords: Judiciary; Principles; Judiciary Principles; Justice; Legal Proceedings; Courts; Independence.

\section{Resumen}

El tema de estudio en este artículo tiene como objetivo educar los conceptos de los principios judiciales en el grupo oriental. Verificamos la conclusión sobre la estructuración constitucional de la formalización de los principios judiciales en las secciones dedicadas a las fundaciones estatales (sistema constitucional); derechos y libertades humanos y civiles; judicial; autoridades judiciales superiores (generalmente el tribunal constitucional). Un estudio jurídico comparativo de las normas de secciones especiales sobre el poder judicial contenidas en las constituciones de los países de Europa del Este permitió al autor formar una lista de principios que organizan y constituyen la base de la actividad de este tipo de poder judicial; identificar la naturaleza específica de su consolidación; Presentar características cuantitativas y cualitativas de los principios fundamentales declarados.

Palabras clave: Poder judicial; Principios; Principios judiciales; Justicia, Procedimientos judiciales, Tribunales, independencia.

\section{Introduction}

The constitution, being a basic law of the state, formalizes the fundamental principles of the organization and activities of various government bodies (Makogon et al., 2017). This is fully consistent with the judiciary (Gribnau, 2002; Zakharov et al., 2019). The subject of this article is a comparative legal aspect of consolidation of the norms and principles of judiciary in the constitutions of Eastern Europe (the texts of such constitutions are taken from the database of the Internet library "Constitutions of states (countries) of the world" (http://worldconstitutions.ru/)) (http://worldconstitutions.ru). The results supplement the judiciary principles previously identified by the author in the human rights based on the example of constitutions of the Eastern European countries (Markhgeym et al., 2019; Treskov, 2019).

\section{Methodology}

The study was based on a dialectic approach to the disclosure of legal phenomena and processes using general scientific (system, logical, analysis and synthesis) and particular scientific methods. The latter include formal-legal, linguistic-legal, comparative-legal ones, which were used together to identify the judiciary principles. 


\section{Discussion and results}

The results showed that special parts/sections are devoted to the judiciary principles ("Court" in Latvia, Lithuania, Estonia; "Courts" in Albania; "Judiciary" in Bulgaria, Hungary, Romania, Slovakia, Croatia, Czech Republic; "Justice" in Macedonia; "Courts and Tribunals" in Poland; "Constitutional Court" in Albania, Bulgaria, Lithuania, Macedonia, Romania, Slovakia, Slovenia, Croatia; "Constitutional Tribunal" and "State Tribunal" in Poland), as well as separate norms of constituent acts on the organization of state authority and the legal status of an individual in the considered group of constitutions. Following the indicated sequence, we will further present key points of the structural integration of the judiciary principles in special parts/chapters of the constitutions. The author has generated and characterized the following list among the latter.

The judiciary principle exercise by a court with varying degrees of detail in the courts/court instances. For example, based on Part 1 of Article 135 of the Constitution of Albania, the judiciary is vested in the Supreme Court, as well as courts of appeal and first instance courts, which are established by law. The enumeration of the types of courts and court instances makes the wording of this principle informatively detailed. We also note the approach of the Constitution of Poland in a similar vein. Its Article 175 includes a provision that justice is administered in the Republic by the Supreme Court, general courts, administrative courts, as well as military courts. In terms of detail, the norms may be considered identical, but there are differences in terminology. The Constitution of Albania uses the term "judiciary", and the Constitution of Poland - "justice".

Laconic formulations of the judiciary principle implementation by the courts are numerous: Article 98 of the Constitution of Macedonia (the courts are repositories of judiciary); Article 115 of the Constitution of Croatia (the courts exercise judiciary) and Article 81 of the Constitution of the Czech Republic (the judiciary is administered by independent courts in the name of the republic).

The approach of using the term "justice" is supported by the constitutions of Hungary, Latvia, Lithuania, Romania, Slovakia and Estonia.

Thus, according to Part 1 of Article 25 of the Constitution of Hungary, the courts perform the administration of justice.

Article 109 of the Constitution of Lithuania and Article 146 of the Constitution of Estonia, justice is administered only by the courts by analogy with the Russian constitutional framework and fairway of the approach under consideration.

The legal structures of the Constitution of Romania are also interesting. Its Article 123 is referred to as the "Administration of justice", but a meaningful specification of the principle is not presented. Then Part 1 of Article 125 "Court Instances" clarifies that justice is administered by the Supreme Court of Justice and other court instances established by law.

Article 86 of the Constitution of Latvia on the administration of justice only by those bodies to which this right is granted by law, and only in the manner prescribed by law, is identical to the Romanian principle.

Part 1 of Article 141 of the Constitution of Slovakia formalizes several principles in conjunction with the one sought: justice in the Slovak Republic is administered by independent and impartial courts. In addition to the fact that justice is administered only by the courts, the latter are declared to be independent and impartial. 
The norm of the Constitution of Bulgaria, which enshrined the principle under consideration through the term "legal proceedings", is different from the approaches presented ... (Part 1 of Article 119).

It is necessary to pay attention to the specific nature of formalizing the administration of justice (judiciary/legal proceedings) or its individual stages on behalf of the state, people or law.

In the first case, examples of Article 109 of the Constitution of Lithuania, Article 174 of the Constitution of Poland, Part 3 of Article 142 of the Constitution of Slovakia, Article 81 of the Constitution of the Czech Republic and Article 117 of the Constitution of Croatia on the proclamation of sentences (court decisions) in the name of the Republic, are identical.

A single version of the formulation of the administration of justice in the name of the people is found in Article 118 of the Constitution of Bulgaria.

In Romania, a single option is similar, but the justice is administered in the name of law (Part 1 of Article 123 of the Constitution).

Prohibition of the establishment of emergency courts. In such a standard formulation, the principle is found in Part 2 of Article 135 of the Constitution of Albania, Part 3 of Article 119 of the Constitution of Bulgaria, Article 98 of the Constitution of Macedonia, Article 148 of the Constitution of Estonia, Part 2 of Article 125 of the Constitution of Romania (it indicates the court instances).

The required principle is absent in other constitutions; however, there are norms that allow us making a conclusion that this basic position is maintained. For example, Article 111 of the Constitution of Lithuania includes a provision according to which the courts with special powers cannot be established in peacetime in the Republic of Lithuania.

According to Article 82 of the Constitution, the justice in Latvia is administered by the district (city) courts, county courts and the Supreme Court, as well as military courts during the war or state of emergency.

There is no directive to prohibit the creation of emergency courts in Poland; however, according to Article 175 of the Constitution, an exceptional court or expedited procedure may be established only during the war.

Thus, presenting an exhaustive list of court types, it is assumed that the creation of others, in particular, emergency ones, is prohibited.

Independence of the courts (Article 109 of the Constitution of Lithuania, Article 95 of the Constitution of Macedonia, Part 1 of Article 141 of the Constitution of Slovakia, Article 115 of the Constitution of Croatia) and their subordination only to the Constitution and laws (Part 1 of Article 145 of the Constitution of Albania, Article 146 of the Constitution of Estonia) / independence of the judiciary (Article 81 of the Constitution of the Czech Republic) and the subordination of judges only to law (Part 2 of Article 117 of the Constitution of Bulgaria). As a rule, an explanation of this principle is given in the wording that interference in the activities of courts or judges entails liability under the law (Part 3 of Article 145 of the Constitution of Albania).

For example, the Constitution of Lithuania does not directly establish the principle of judiciary's independence. However, a separate Article 114 speaks in favor of its isolation in connection with the impossibility of interference in the activities of a judge or a court. 
The principle under consideration is presented in the Constitution of Poland in direct and contextual formulations. Its Article 173 states that the courts and tribunals are separate and independent from other authorities.

The independence is partly referred to in Article 186 of the Constitution of Poland, when the General Council of Justice is on guard of the independence of courts and judges.

Public consideration of cases in all the courts, unless otherwise provided by law (Part 3 of Article 121 of the Constitution of Bulgaria). Article 126 of the Constitution of Romania adopted a similar format.

The term "openness" is also used in formulating this principle of the constitution. Article 117 of the Constitution of Lithuania formalizes that the proceedings should be open in all courts. And the closed court cases are clarified.

It is interesting that Part 2 of Article 96 of the Constitution of the Czech Republic, in addition to openness of the proceedings, fixes their oral nature.

The principle of publicity (openness) of the court session is coupled with the publicity (openness) of the case consideration in court. Thus, the constitutions of Macedonia, Croatia, and the Czech Republic (Part 2 of Article 96) consolidate them in one norm.

According to Article 102 of the Constitution of Macedonia, the case hearing and the decision announcement should be open in the courts. Article 117 defines public case hearing and decision announcement in the courts.

Part 3 of Article 142 of the Constitution of Slovak secures publicity of a court sentence pronouncement.

The publicity of court decisions is formalized as a separate norm in Albania: the Supreme Court of Albania should publish its decisions, as well as special opinions of the minority (Part 2 of Article 142); court decisions are announced publicly in each case (Part 2 of Article 146).

The independence of courts (Article 98 of the Constitution of Macedonia) and the independence of judiciary (Article 115 of the Constitution of Croatia) as principles are identified in a limited number of constitutions.

The budgetary independence of courts is expressed in the constitutional structures such as "the courts have a special budget, which they manage at their discretion. They use their budget in accordance with the law" (Article 144 of the Constitution of Albania). Part 3 of Article 117 of the Constitution of Bulgaria includes concise statement: the judiciary has an independent budget.

The principle of the legality of the organization and activities of the judiciary is almost literally reflected in Article 133 of the Constitution of Bulgaria as "the organization and activities of ... the courts ... and the exercise of their responsibility are regulated by law."

The formation and competence of the courts on the basis of the law is referred to in Article 111 of the Republic of Lithuania. The wordings of Article 126 of the Constitution of Slovenia (Treskov, 2019) and Part 2 of Article 91 of the Constitution of the Czech Republic on the powers and organization of courts on the basis of law, are quite similar.

In addition to the structure and competence, Article 176 of the Constitution of Poland and also mentions the procedure for legal proceedings. The norm specified in Part 3 of Article 125 of the Constitution of Romania is similar. 
According to Part 2 of Article 143 of the Constitution of Slovakia, the system of courts, their competence, organization and proceedings in them are subject to detailed regulation by law.

Compared with the above, the provisions of Article 98 of the Constitution of Macedonia on legal proceedings on the basis of the Constitution and laws, as well as international treaties ratified in accordance with the Constitution, are more detailed.

This norm determines that the types, competencies, creation, cancellation, structure and composition of courts, as well as preliminary investigations are established by law adopted by a two-thirds majority of the total number of deputies.

Thus, in addition to special procedure for the adoption of laws relating to the courts, the norm also fixed the basis of constitutional norms, as well as international treaties.

Article 115 of the Constitution of Croatia and Article 146 of the Constitution of Estonia are identical in terms of fixing the administration of justice on the basis of the Constitution and laws.

They also contain the norms detailing the legitimacy of organization and activities. Article 116 of the Constitution of Croatia states that the establishment, competence, composition and organization of the courts, as well as legal proceedings, are regulated by law. Article 149 of the Constitution of Estonia more succinctly establishes the judiciary and the judicial procedure by law.

It should be noted that the principle of collegiality and unity of activities of the court and judge was revealed in terms of the organization of activities in Article 103 of the Constitution of Macedonia.

We found the principles comparable with judicial decisions in the group of constitutions under consideration. Thus, the constitutions of Albania and Bulgaria state about the proveness (Part 1 of Article 142) and motivation (Part 4 of Article 121) of the court decisions accordingly. Part 3 of Article 142 of the Constitution of Albanian formalized the principle of binding court decisions for the state bodies.

Then, let us pay attention to the block of procedural principles. It is advisable to specify the principle of equality and competitiveness of the parties in the wording of Part 1 of Article 121 of the Constitution of Bulgaria, when the courts ensure equality and conditions for the adversarial process of the parties in the trial.

According to Part 1 of Article 96 of the Constitution of the Czech Republic, all participants in the trial should have equal rights.

The principles under consideration include the state language of legal proceedings, formalized in Article 117 of the Constitution of Lithuania with the explanation that persons who do not speak the Lithuanian language are guaranteed the right to participate in the investigative and judicial actions through an interpreter.

Part 1 of Article 127 "Right to have an interpreter" of the Constitution of Romania stipulates that the proceedings should be conducted in Romanian, with further clarification of the interpreter provision rules.

As we stated earlier, the constitutions of the Eastern Europe countries, in addition to special sections/chapters on the courts (judiciary), formalized special sections/chapters on higher 
judicial bodies. We emphasize that the constitutions, which include two indicated varieties of sections/chapters in their structure, arrange them in different sequences without taking into account the criterion of "general - particular" or other parameters.

Let us note once again that the highest judicial bodies, the status of which is determined at the constitutional level, are the Constitutional Courts as a rule. In this regard, the parts/sections on them contain the principles related to the legality of organization and activities, as well as the nature of decisions they make. These principles are specified in aggregate or single version and are formalized in the constitutions of the Eastern European countries.

The principles of decisions taken are exclusively referred to, for example, in the Constitution of Albania: universality, binding and final decisions of the Constitutional Court (Part 1 of Article 132).

Article 107 of the Constitution of Latvia refers to the finality of decisions of the Constitutional Court and the impossibility of appealing them.

Part 2 of Article 145 of the Constitution of Romania "Decisions of the Constitutional Court" specifies that the decisions of the Constitutional Court are binding and are valid only for the future. It has been clarified that they are published in the Monitorul Oficial al Romaniei.

The next block of constitutions formalized the principles of organization and activities of the Constitutional Court. Article 152 of the Constitution of Bulgaria on the organization and activities of the Constitutional Court on the basis of law is to the point here. Article 140 of the Constitution of Slovakia states that the organizational details of the Constitutional Court, the procedure of its proceedings and the provisions of its judges are established by law.

The indicated principles are collectively fixed in the next group of constitutional norms.

Thus, on the basis of Article 112 of the Constitution of Macedonia, the decisions of the Constitutional Court of the Republic are final and subject to mandatory enforcement.

There is a provision on determination by the Court of the organization and activities of the Constitutional Court of Macedonia in Article 113 of the Constitution. As we can see, the above statement differs in the procedural basis of organization and activities. In this case, this is not the law, but the Court itself.

Let us clarify that the Constitution of Poland also has an independent part on the Constitutional Tribunal. It contains the following fundamental theses:

- decisions of the Constitutional Tribunal are binding and final (Article 190);

- organization of the Constitutional Tribunal, as well as the proceedings before the Tribunal, are determined by law (Article 197).

It should be noted that the Constitution of Poland breaks out a part devoted to the State Tribunal. Article 201 enshrines that the organization of the State Tribunal, as well as the proceedings before the Tribunal, are determined by law.

It should be noted that Part IV "Economics and Public Finances" of the Constitution of Romania establishes the status of the Court of Accounts, which monitors the formation of financial resources of the state and the public sector, their management and use (Article 139).

We found no fundamental provisions on it; however, the principles addressed to judges are present (Part 4 of Article 139): members of the Court of Accounts appointed by the Parliament are independent and irremovable in accordance with the law. 
Let us note there is no self-made chapter on the Constitutional Court in the Constitution of the Czech Republic, but Article 89 of Chapter 4 "Judiciary" is devoted to this judicial authority and secures the following set of principles:

- the decision of the Constitutional Court is enforceable, if it was made public in the manner prescribed by law, unless otherwise provided by a decision of the Constitutional Court;

- the decision of the Constitutional Court to be enforced is binding on all bodies and citizens.

Unlike the Czech experience, the constitutions of Hungary, Slovenia and Croatia include no essential provisions in separate articles on the Constitutional Court.

It should be noted that we identified some constitutions that contain quantitatively limited norms and principles on the judiciary in the group of constitutions studied. For example, this is the Constitution of Bosnia and Herzegovina. Its Article II "Human rights and fundamental freedoms" contains the principle of respect for human rights and fundamental freedoms by the courts. In addition to this norm, there is still Article VI "The Constitutional Court", according to which the decisions of the Constitutional Court are final and binding.

\section{Conclusions}

As we see, the judiciary principles are not always integrated in a special constitutional section. Thus, the Constitution of Slovenia does not contain a special chapter on the courts and judiciary; however, the principles sought are mostly (in quantitative and qualitative aspects) concentrated in Section II "Human rights and fundamental freedoms", although there is a section devoted to the Constitutional Court. The approach of the Constitution of Romania, which formalized the judiciary principles in Part II "Fundamental rights, freedoms and duties", Part IV "Economics and public finances", as well as Part V "The Constitutional Court", is similar.

In general, the constitutional experience of Eastern European countries regarding formalization of the judiciary principles may be regarded as meaningfully multidimensional and complete from the point of view of legal regulation of various judiciary aspects. This is presupposed by the quantitative and qualitative composition of the principles themselves, the terms with which they are expressed, as well as the standard and specific legal constructions of their formalization. Disclosure of declared judicial principles requires a comprehensive analysis of all sections/parts of the constitutions to obtain their holistic perception.

\section{References}

Gribnau, H. (2002, June). Legitimacy of the Judiciary. In E. Hondius and C. Joustra (red.), Netherlands Reports to the Sixteenth International Congress of Comparative Law, Antwerpen [etc.]: Intersentia (pp. 25-45).

http://worldconstitutions.ru/ (accessed 19 March 2019).

Makogon, B. V., Nikulin, M. I., Samsonov, V. N., Sorokoletova, M. A., \& Tovstukha, O. O. (2017). Objectives and Principles of Administrative Proceedings: Doctrinal Ideas and Legislative Wordings of the Eastern European Countries. Journal of Politics and Law, 10(4), 221-224.

Markhgeym, M. V., Mikhaleva, G. G., Novikova, A. E., Treskov, A. P., \& Tonkov, E. E. (2019). HUMANITARIAN CONTEXT OF THE PRINCIPLES OF THE JUDICIARY IN THE CONSTITUTIONS OF THE COUNTRIES OF EASTERN EUROPE. Humanities \& Social Sciences Reviews, 7(5), 1035-1038. 
Treskov, A.P. (2019). Structural integration of constitutional principles of the judiciary: Eastern European experience. Socio-political sciences, 9(2), 95-98. (In Russian)

Zakharov, S., Chemshit, A., Novikova, A., Stus, N., \& Zajceva, T. (2019). Justice independence: foreign constitutional experiences. Dilemas Contemporáneos: Educación, Política y Valores, 6(3). 